\title{
PERUBAHAN WARNA IKAN MAS Cyprinus carpio DENGAN PENAMBAHAN EKSTRA BUAH PALA Myristica argentha PADA DOSIS BERBEDA
}

\author{
Sutia Budi ${ }^{1}$, Mardiana ${ }^{1}$, Geris $^{2}$ dan Gusti Tantu ${ }^{3}$ \\ E-mail: sutiab@yahoo.com \\ ${ }^{1}$ Progam Studi Budidaya Perairan, Fakultas Pertanian, Universitas Bosowa \\ ${ }^{2}$ Penyuluh Perikanan Dinas Perikanan dan Kelautan Kabupaten Flores Timur \\ ${ }^{3}$ Progam Studi Budidaya Perairan, Program Pascasarajana, Universitas Bosowa
}

\begin{abstract}
ABSTRAK
Ikan Hias jenis ikan Mas Koi Cyprinus carpio memiliki daya tarik pada warna yang dimunculkan dari tubuhnya. Dagung buah Pala Myristica argentha memiliki pigmen karotenoid, asam askorbat, flavenoid, phenol asit dan lutein. Penelitian ini bertujuan untuk mengetahui perubahan warna merah tubuh ikan Mas Koi Cyprinus carpio melalui pemberian ekstrak kasar pala dengan dosis yang berbeda. Parameter peubah yang diukur berupa perubahan warna dengan menggunakan scoring melalui metode modifikasi TCF. Wadah penelitian menggunakan toples transparan $5 \mathrm{~L}$, dengan volume air sebanyak 3,5 L per wadah. Hewan uji yang digunakan adalah ikan Mas dengan panjang $10 \pm 3,6 \mathrm{~cm}$ dengan kepadatan 1 ekor per wadah. Perlakuan yang di uji adalah berbagai konsentrasi ekstrak kasar buah pala dalam pakan, yakni $\mathrm{A}=0 \%, \mathrm{~B}$ $=5 \%, \mathrm{C}=10 \%$ dan $\mathrm{D}=15 \%$, dengan masing - masing 3 kali ulangan. Hasil penelitian menunjukkan bahwa perlakuan berbagai konsentrasi ekstrak pala memberikan pengaruh terhadap perubahan warna merah tubuh ikan Mas Koi.
\end{abstract}

Kata Kunci: Ikan Koi, Pala, Warna, Dosis

\section{A. PENDAHULUAN}

Ikan Mas Koi Cyprinus carpio adalah salah satu jenis hewan peliharaan yang mempunyai daya tarik pada warna yang dimunculkan dari tubuhnya. Berbagai warna-warni indah pada ikan pada dasarnya dihasilkan oleh sel-sel pigmen (chromatophore) yang terletak pada kulit ikan. Keindahan bentuk sirip dan warna sangat menentukan nilai jual. Warna pada ikan Koi mempunyai fungsi yang signifikan, yaitu sebagai pengenal jenis yaitu dari tampilan pola dan corak warna pada tubuhnya. Warna pada ikan umumnya muncul pada periode-periode tertentu, khususnya pada saat menjelang musim kawin. Kondisi lingkungan yang mempunyai intensitas pencahayaan yang tinggi akan membuat warna ikan semakin cerah serta ketersediaan nutrisi yang tepat pada pakan misalnya kandungan karotenoid. Warna tubuh yang indah dan bervariasi merupakan daya tarik sebagai ikan hias. Warna indah pada ikan disebabkan oleh kromatofor (sel pigmen) yang terletak pada lapisan epidermis, yang memiliki kemampuan untuk menyesuaikan dengan lingkungan dan 
aktifitas seksual, sedangkan jumlah dan letak pergerakan

kromatofor mempengaruhi tingkat kecerahan warna pada ikan (Lesmana, 2004). Kromatofor dapat diklasifikasikan menjadi 5 kategori warna dasar yaitu melanofor, eritrofor, xantofor, leukofor, dan iridofor (Anderson, 2000; Sally, 1997).

Salah satu tanaman yang memiliki kandungan karotenoid adalah buha Pala Myristica argentha. Selain mineral, buah pala juga mengandung berbagai macam vitamin penting seperti B-kompleks, termasuk vitamin $\mathrm{C}$, asam folat, riboflavin, niasin, vitamin $\mathrm{A}$, flavonoid, dan Beta-karoten (Caratik, 2013). Betakaroten merupakan pigmen penyebab warna putih kekuning kuningan pada buah. Betakaroten merupakan nutrient yang baik untuk kesehatan dan antioksidan. Betakaroten juga merupakan sumber utama dalam proses pigmentasi pada ikan hias atau ikan daerah tropis, untuk berbagai macam spesies ikan berwarna merah, kuning, dan warna lainnya (Meyers, 1994). Mafolimbo (2002) mengatakan bahwa karotenoid berfungsi sebagai antioksida yang tinggi dalam menghambat reaksi radikal bebas.

Kandungan pigmen dalam pakan merupakan salah satu faktor yang mempengaruhi kecerahan warna ikan
(Bachtiar, 2003). Upaya untuk meningkatkan kecerahan warna ikan dengan menambahkan karotenoid yang merupakan komponen pembentuk warna merah dan kuning (Satyani dan Sugito, 1997). Astaxantin yang ditambahkan dalam pakan ikan merupakan salah satu karotenoid yang dominan dan efektif untuk meningkatkan kecerahan warna ikan, karena ikan akan menyerapnya dari pakan dan menggunakan langsung sebagai sel pigmen warna merah (Gupta and Jha, 2006; Lesmana dan Satyani, 2002).

Penelitian tentang pigmentasi pada ikan hias telah banyak di lakukan (Ezhil, 2008). Sukarman dan Chumaidi (2010) melakukan penelitian tentang bunga Tai Kotok Tagetas sp sebagai sumber karotenoid pada ikan hias. Budiardi dkk. (2005) meneliti tentang pigmentasi dan pertumbuhan pada ikan dengan jenis pakan alami berbeda. Shiang (2006) tentang perubahan warna ikan hias dengan menggunakan sumber karotenoid yang berbeda pada pakan, sedangakan penggunaan Pala Myristica argentha sebagai sumber pakan belum dilakukan sehingga berdasarkan hal tersebut perlu dilakukan suatu penelitian buah pala Myristica argentha terhadap peningkatan kualitas warna, pertumbuhan dan 
kelangsungan hidup pada ikan Koi. yang diujikan adalah perbedaan dosis Penelitian ini bertujuan untuk memperoleh informasi tentang status pola peningkatan pigmentasi pada ikan Koi Cyprinus carpio dengan mengukur proses perubahan warna merah pada tubuh ikan Koi serta mengevaluasi dosis ekstrak kasar daging buah Pala Myristica argentha yang optimal untuk peningkatan kualitas warna tubuh ikan Koi. Hasil penelitian ini diharapkan menghasilkan suatu model substitusi pakan yang optimal yang dapat menjadi paket teknologi yang tepat untuk budidaya guna meningkatkan produksi secara berkesimbungan.

\section{B. METODE PENELITIAN}

Penelitian dilaksanakan di Laboratorium Budidaya Perairan, Jurusan Perikanan, Universitas Bosowa Makassar. Materi penelitian ini berupa ekstrak kasar buah Pala dan pakan komersil. Sebagai hewan uji digunakan jenis ikan Mas Koi Cyprinus carpio berumur 2 bulan dengan ukuran $10 \pm 3,6 \mathrm{~cm}$. Kepadatan ikan Mas yang digunakan pada penelitian ini adalah 1 ekor./L. Wadah penelitian berupa toples transparan berukuran $5 \mathrm{~L}$. Penelitian didesain dengan rancangan acak lengkap dengan 4 perlakuan dan masing - masing tiga ulangan. Perlakuan ekstrak Pala dalam pakan yang diberikan, yaitu perlakuan A $(0 \%)$, perlakuan B (5 $\%)$, perlakuan C (10\%) dan perlakuan D $(15 \%)$.

Pembuatan ekstrak kasar buah Pala adalah mengeringkan daging buah Pala selama 3 - 4 hari, setelah kering dipotong kecil-kecil kemudian dihaluskan. Pakan komersil dicampur dengan ekstrak kasar Pala yang berfungsi sebagai substitusi bahan karotenoid dalam pakan dengan mengunakan putih telur dan air sebagai perekat kemudian dikeringkan. Pemberian pakan pada pagi hari dengan komposisi 5 $\%$ dari berat tubuh ikan. Pergantian air dilakukan setiap 3 hari sekali dengan frekuensi $100 \%$. Pengukuran parameter uji dilakukan setiap minggu selama 5 minggu.

Analisa tingkat kecerahan warna ikan Mas menggunakan metode modifikasi Toca Colour Finder yang telah diberi skor (1 - 6). Bagian tubuh ikan Mas Koi yang diamati pada tubuh ikan yang berwarna merah. Penentuan kriteria tingkat kecerahan menggunakan rumus interval:

Nilai $=\frac{\text { nilai tertinggi }- \text { nilai terendah }}{\text { kelas }}$

Data yang diperoleh dianalisis secara deskriftif dengan menggunakan skoring. Nilai skoring yaitu $1-1.9$ 
(gelap), 1 - 2.9 (sangat buram), $3-3.9$ (buram), $4-4.9$ (sedang), 5 - 5.9 (cerah), dan $6-6.9$ (sangat cerah). Analisis ragam dilakukan untuk melihat pengaruh ekstrak buah pala terhadap tingkat kecerahan ikan Koi. Apabila terdapat pengaruh dilanjutkan uji lanjut Tuckey untuk melihat perlakuan yang berbeda.

\section{HASIL DAN PEMBAHASAN}

Hasil pengukuran menunjukkan perubahan warna tubuh ikan Mas Koi Cyprinus carpio dengan pemberian ekstrak kasar buah Pala Myristica argentha mengalami perbedaan setiap waktu pengamatan. Peningkatan warna terjadi sampai pada minggu ketiga kemudian mengalami penurunan pada menggu keempat, kemudian meningkat lagi pada minggu kelima. Perlakuan tanpa ekstrak Pala menunjukkan stagnasi kualitas warna tubuh namun pada minggu keempat baru mengalami peningkatan. Laju perubahan warna tubuh ikan (merah) dapat lihat pada Gambar 1.

Gambar 1., menunjukkan nilai rata-rata yaitu perlakuan A $(0 \%) 4.9 \pm 0.7$ kategori sedang, perlakuan B (5\%) $5.6 \pm 0.5$ kategori cerah, perlakuan C (10\%) $5.9 \pm$ 0.6 kategori cerah dan perlakuan D (15 \%) $5.9 \pm 0.7$ kategori cerah. Kategori perubahan warna ikan Mas Koi umumnya Buram - Cerah. Sedangkan hasil analisis ragam (Anova) menunjukkan terdapat pengaruh $(\mathrm{P}<0.05)$ pemberian ekstrak Pala dalam pakan Ikan Mas Koi terdapat tingkat kecerahan tubuh ikan. Hasil uji lanjut menunjukkan perlakuan A (0 \%) berbeda $(\mathrm{P}<0.05)$ dengan perlakuan $\mathrm{C}$ $(10 \%)$ dan D (15 \%) namun tidak berbeda dengan perlakuan B (5\%) (P $>0.05)$.

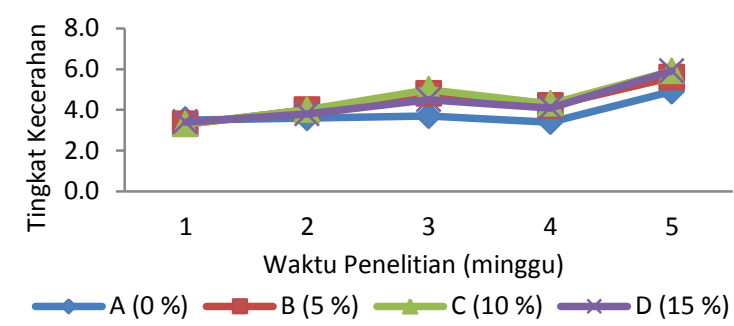

Gambar 1. Perubahan warna tubuh ikan Mas Koi pada masing-masing perlakuan

Peningkatan kualitas warna tubuh ikan ikan Mas pada Gambar 1, menunjukkan pengaruh ekstrak kulit pala mampu mempertahankan kualitas warna. Kebutuhan ikan terhadap pigmentasi yang berasal dari karotenoid buah Pala, hanya dibutuhkan dalam jumlah dan waktu yang sesuai dengan kebutuhan proses metabolisme. Hal ini sesuai dengan Fujaya (2004), bahwa kemampuan ikan dalam menyerap karotenoid dalam jumlah terbatas.

Terjadinya peningkatan kecerahan yang diberi perlakuan ekstrak pala dibandingkan dengan tanpa ekstrak menunjukkan bahwa ekstrak Pala dapat 
diserap dan disintesis dengan baik oleh ikan Mas Koi. Perlakuan B (5 \%), C (10 $\%$ ) dan D (15\%), dari minggu pertama sampai akhir penelitian mengalami peningkatan skor kecerahan warna, yakni dari Buram menjadi Cerah. Sedangkan pada perlakuan A (0 \%), menunjukkan tidak terjadi perubahan warna. Perlakuan dosis $5 \%$ sampai dengan $15 \%$ menunjukkan bahwa penambahan setiap 5 \% ekstrak Pala pada pakan tidak memberikan perbedaan peningkatan warna yang signifikan. Hal ini menunjukkan bahwa dengan dosis $5 \%$, kecerahan warna pada tubuh ikan Mas Koi telah mampu meningkat secara optimal. Amin et al. (2012), untuk memperoleh penampilan warna terbaik pada ikan, maka dosis sumber pigmen warna yang diberikan harus tepat. Hal ini sesuai dengan Shiang (2006) bahwa pembangkit warna hanya diperlukan dalam jumlah seperlunya sesuai dengan kemampuan sel-sel pengatur warna pada ikan karena pemberian zat pewarna secara berlebihan akan dibuang oleh ikan.

\section{KESIMPULAN}

Pemberian ekstrak kasar buah Pala pada pakan ikan Mas Koi memberikan pengaruh yang baik terhadap peningkatan kecerahan warna. Ekstrat Pala yang mengandung karotenoid berperan dalam mempertahankan kualitas warna khususnya merah pada tubuh ikan Mas Koi. Disarankan dosis terbaik sebesar 5 $\%$, karena setelah kisaran dosis tersebut tidak memberikan pengaruh terhadap peningkatan kecerahan ikan Mas Koi.

\section{DAFTAR PUSTAKA}

Amin, M. I., Rosidah dan Walim Lili, 2012. Peningkatan Kecerahan Warna Udang Red Cherry Neocaridina heteroposa Jantan Melalui Pemberian Astaxanthin dan Canthaxabthin dalam Pakan. Jurnal Perikanan dan Kelautan. Vol. 3 No. 4. Hal. 243 - 252.

Anderson, S. 2000. Salmon Colour and Consumer. Hoffman-La Roche, Cambridge Ontario. Canada.

Bachtiar, Y. 2003. Pakan Alami untuk Ikan Hias. Agromedia Pustaka. Jakarta

Dahlifa, D., Budi, S., \& Aqmal, A. (2016). Penggunaan Tepung Kulit Manggis Garcinia Mangostana Untuk Meningkatkan Pertumbuhan, Indeks Hematokrit Dan Tingkat Kelangsungan Hidup Ikan Mas Koi Cyprinus Carpio. Octopus: Jurnal Ilmu Perikanan, 5(2), 481-487.

Budi, S., Karim, M. Y., Trijuno, D. D., Nessa, M. N., \& Herlinah, H. (2018). Pengaruh Hormon Ecdyson Terhadap Sintasan Dan Periode Moulting Pada Larva Kepiting Bakau Scylla olivacea. Jurnal Riset Akuakultur, 12(4), 335-339. 
Dalimartha, S. 2003. Atlas Tumbuhan Obat Indonesia. PT. Puspa Swara. Jakarta.

Ezhill. J. Et al. 2008. Marigold as a carotenoid source on pigmentation and growth of Red Swordtail, Xiphophorus helleri. Turkish J. Of Fisheries and Aquatic Sciences. Vol 8.

Fujaya, Y., 2004. Fisiologi Ikan. Penerbit Rineka Cipta. Jakarta

Gupta, S. K. and Jha, A. K. 2006. Use of Natural Carotenoids for Pigmentation in Fishes. Central Institute of Fisheries Education, Seven Bunglows. India.

Hidayat, N., 2007. Komponen Nutrisi Lombok (Capsicum annmun L). (Online).(http://ptp2007/12/29/k omponen-nutirisi-lombok capsicum-annmun/) di askes 17 januari 2013.

Lesmana, D.S. 2004. Kualitas Air Untuk Ikan Hias Air Tawar. Penebar Swadaya. Jakarta.

Lesmana dan Satyani, D. 2002. Agar Ikan Hias Cemerlang. Penebar Swadaya. Jakarta.

Mafolimbo, E., 2002, Evaluation of Capsicum as a source of Natural Antioxidant in Preventing Rancidity in Sunflower Oil, The Journal of Food Technology in Africa, Vol.7, Apr-Jun, 2002.

Pinandoyo, 2005. Pengaruh Berbagai Kadar Carophyll Pink dan Tepung Wortel Dalam Pakan Buatan Terhadap Kecerahan Ikan Oscar (Astronotos ocellatus cuvier) Universitas

Diponegoro.Semarang.

Sally, E. 1997. Pigment Granula Transport in Cromatophores. Departement of Biology Bucknell University, Lewisburg.
Satyani, D dan Sugito, S. 1997. Astaxanthin Sebagai Suplemen Pakan untuk Peningkatan Warna Ikan Hias. Warta Penelitian Perikanan Indonesia. Vol III. Jakarta.

Shiang, Tan Phaik. 2006. Skin Colour Changes in Ornamental Koi (Cyprinus Carpio) Fed Defferent Dietary Carotenoid Sources.Universitas Sains Malaysia.

Sukarman dan Chumaidi, 2010. Bunga Tai Kotok (Tagetas sp.) sebagai sumber Karotenoid Pada Ikan Hias. Balai Riset Budidaya Ikan Hias. Depok. 